\title{
CZY BATIK JEST SYMBOLEM TOŻSAMOŚCI NARODOWEJ W INDONEZJI? NARODZINY I ROZWÓJ INDONEZYJSKIEGO STROJU NARODOWEGO
}

\author{
IS BATIK A SYMBOL OF THE NATIONAL IDENTITY \\ IN INDONESIA? \\ THE BIRTH AND THE TRANSFIGURATION \\ OF INDONESIAN NATIONAL COSTUME
}

\begin{abstract}
This study investigates the national costume in Indonesia, especially one of its components - batik. Is batik a symbol of Indonesian national identity, or is it just a proof of domination of the Javanese culture? In this article, I explore the ways in which batik became a popular costume for Indonesian citizens, defined also as a vehicle for manifestations of many different ideas and identities. I analyze not only briefly a history of batik as a part of Indonesian national costume, but also the ways of its understanding, both in the past an in conteporary Indonesia.
\end{abstract}

Key wo rds: batik; Indonesia; national identity; costume; Java

\section{Streszczenie}

Przedmiotem analizy w niniejszej pracy jest indonezyjski strój narodowy, zwłaszcza jeden z jego elementów - batik. Czy batik jest symbolem tożsamości narodowej w Indonezji, czy jedynie stanowi dowód na dominację kultury jawajskiej? W ar-

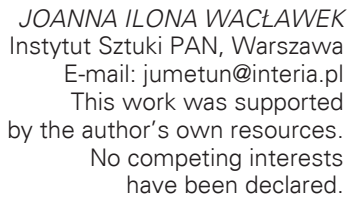

This is an Open Access article distributed under the terms of the Creative Commons Attribution 3.0 PL License (creativecommons.org/licenses/by/3.0/pl/), which permits redistribution, commercial and non-commercial, provided that the article is properly cited. (C) The Author(s) 2015.

Publisher: Institute of Slavic Studies, Polish Academy of Sciences [Wydawca: Instytut Slawistyki PAN] 
tykule omawiam ścieżki transformacji batiku w ubiór, bądź część ubioru, noszony przez Indonezyjczyków, definiowany zarazem jako przestrzeń służąca manifestowaniu rozmaitych poglądów, przekonań i tożsamości. Badam nie tylko historię batiku jako elementu narodowego stroju w Indonezji, lecz także sposoby jego odczytywania, zarówno w przeszłości, jak i obecnie.

Stowa kluczow e: batik; Indonezja; tożsamość narodowa; strój narodowy; Jawa

To be Javanese is to be Indonesian but the reverse is clearly not the case.

Woodward, 2011, s. 14

W piątek 17 kwietnia 1945 roku w Dżakarcie Ahmed Sukarno ogłosił niepodległość Indonezji w imieniu narodu indonezyjskiego (bangsa Indonesia). Na zdjęciu dokumentującym to wydarzenie przyszły pierwszy prezydent Indonezji nosi białe spodnie z mankietami, białą jednorzędową marynarkę o wojskowym kroju oraz peci, męskie nakrycie głowy w kolorze czarnym, podobne do fezu. Nieco z boku widoczny jest również Mohammad Hatta, przyszły pierwszy premier Indonezji, ubrany w lekki biały garnitur i białą koszulę. Ze wszystkich uchwyconych na zdjęciu osób tylko Sukarno nosi peci, mężczyźni zebrani za nim i stojący obok mają głowy odkryte lub noszą kapelusze; jeśli nie są ubrani w mundury wojskowe, mają na sobie stroje europejskie. Jedynie stojąca pośród nich kobieta, zapewne trzecia żona Sukarno, Fatmawati', wydaje się bardziej pasować do stereotypowych wyobrażeń Indonezji u zarania niepodległości - włosy ma lekko okryte rodzajem zwiewnego szala, określanym jako kerudung bądź kudung, nosi kebayę i prawdopodobnie batikowy materiał owinięty wokół bioder, co jednak jest już zbyt słabo widoczne. Niemniej można się tego domyślać, analizując inne zdjęcia pierwszej pary, wykonywane zarówno podczas oficjalnych spotkań politycznych, jak i tych bardziej prywatnych, ukazujących życie rodzinne prezydenta.

Batik jest techniką zdobienia podłoża, najczęściej tkaniny, poprzez pokrywanie wybranych jej przestrzeni ciekłym woskiem. Całość można, po zakrzepnięciu, poddać procesowi farbowania, a następnie usunięcia wosku, uzyskując niezabarwione pola. W zależności od potrzeb tkaninę można barwić wielokrotnie, uzyskując złożone efekty kolorystyczne i niezwykle misterne i delikatne wzory. Pierwotnie słowo batik oznaczało jedynie tkaninę wykonaną tą techniką, a służącą do owinięcia wokół ciała, nie zszywaną ani nie ciętą po batikowaniu. Współcześnie odnosi się ono także do materiału we wzór "batikowy" oraz gotowego elementu odzieży uszytego z takiego materiału². Prosząc o batik na indonezyjskim, zwłaszcza jawajskim targu, możemy więc otrzymać nie tylko kupon ręcznie pokrywanego lub stemplowanego woskiem i farbowanego materiału, tzw. kain, ale też taki, który nigdy nie był pokryty woskiem, a jedynie masowo wyprodukowany, o wzorach batikowych utrwalonych w tradycji bądź też nowych, niemniej jednak rozpoznawanych przez sprzedającego i kupującego jako batikowe. Technika batiku obecnie wykorzystywana jest w Indonezji nie tylko do zdobienia tkanin. Batikowane mogą być przedmioty drewniane, metal, plecione maty. Czasami w zdobnictwie wykorzystywany jest, jako element dekoracyjny, sam ornament uznawany za "batikowy”, który zostaje na przykład wygrawerowany na szklanej tafli drzwi.

Sukarno był żonaty dziewięć razy.

2 Bądź torebek, obrusów, poszewek na poduszki itp. 
Choć technika ta znana jest nie tylko na Jawie, to właśnie na dworach lokalnych władców jawajskich wykształcił się najbardziej wyrafinowany system znaczeń i hierarchii motywów, przy jednoczesnym mistrzostwie wykonania batikowych tkanin.

Batik, jako element stroju, niemal od początku niepodległej Indonezji stał się przestrzenią retoryczną, budzącą w przywódcach politycznych przekonanie, że poprzez nią mogą opanować przeszłość, teraźniejszość i przyszłość dyskursu o narodowej tożsamości. Odbijał program unifikacji państwa, szczególnie istotny dla polityki pierwszych dwóch prezydentów: Sukarno i Mohameda Suharto, obnażając jednak zarazem nierówne podstawy, na których wznoszono fundamenty jedności kraju. Ukazywał także dominację kultury jawajskiej jako primus inter pares. Symbolem tego był strój jawajski, a raczej spopularyzowana w XIX wieku wersja stroju arystokratycznego, przeobrażona w strój narodowy Indonezji, którego najważniejszym elementem, z upływem lat, stał się batik.

Reliefy z hinduistycznych i buddyjskich świątyń jawajskich, datowanych na około ósmy i dziewiąty wiek, pozwalają wyobrazić sobie, jak wówczas wyglądały stroje jawajskiej arystokracji. Były to długie pasy materiału, drapowane wokół ciała (por. Taylor, 2010, s. 102). Relacje podróżników z XVI i XVII wieku zawierają wzmianki o powszechnie stosowanym przez kobiety i mężczyzn stroju składającym się z owijanego lub drapowanego od pasa do kolan lub kostek materiału, zaś w przypadku kobiet dodatkowej tkaniny owijanej wokół piersi (Taylor, 2010, s. 102). Z kolei grafiki, między innymi staloryt nr 24, ze zbioru Oceania, z drugiej połowy lat trzydziestych XIX wieku, ukazują stroje Jawajczyków z różnych warstw społecznych, także wykorzystujących odmienne dla każdego stanu i pozycji warianty drapowania tkanin, w przeważającej swej liczbie batikowych ${ }^{3}$.

W jawajskich strojach i zdobiących je motywach wyraźne są wpływy innych kultur, z którymi przez stulecia Jawajczycy nawiązywali mniej lub bardziej pokojowe, często oparte na wymianie handlowej, kontakty. Przede wszystkim były to kultury indyjska, arabska i europejska ${ }^{4}$, nie będąc jednak wyłącznymi źródłami inspiracji i nawiązań. Jeden z elementów kobiecego stroju arystokratycznego, upowszechniony wśród wszystkich warstw społecznych, związany jest najprawdopodobniej z kontaktami z Chinami. W XV wieku w Malakce, ważnym porcie na Półwyspie Malajskim, umożliwiającym wymianę dóbr w regionie, a także w portach na Jawie i Sumatrze, coraz chętniej osiedlała się ludność pochodzenia chińskiego ${ }^{5}$. Byli to potomkowie Chińczyków i miejscowych kobiet (Seri, 2004, s. 24), w swoich strojach i zwyczajach łączący elementy lokalne z chińskimi. To prawdopodobnie dało początek późniejszej kebai, czyli rodzajowi lekkiego żakietu bądź koszuli, spopularyzowanego na szerokim obszarze poprzez kontakty handlowe 6 . Kebaya występowała w wielu fasonach, mogła być bogato zdobiona haftami bądź gładka, z materiału transparentnego lub z tkaniny nieprzezroczystej. Wśród rdzennej ludności Jawy do XIX wieku wykształciła się i upowszechniła7 jej forma przypominająca połączenie tradycyjnego na tym obszarze wąskiego pasa tkaniny okręcanego wokół piersi,

3 Staloryt (odbitka) George'a Louisa Domeny'a de Rienci, zbiory prywatne autorki. Grafika ukazuje stroje pary z gminu, tancerki, dworzanina oraz strażnika dworskiego.

$4 \quad$ Z obcej kultury zapożyczony został między innymi sam zwyczaj okrywania ramion, podobnie jak późniejsze wykorzystywanie w stroju elementów szytych (jak marynarki, bluzy, bądź spodnie), z którymi Europejczycy zapoznali Jawajczyków około XV wieku.

5 Handel z Chinami rozwijał się w regionie co najmniej od trzeciego stulecia. Podkreśleniem istoty kontaktów pomiędzy sultanatem Malakki i Chinami, był ślub sułtana Mansur Shaha z księżniczką Hang Li Po w 1462 roku (patrz: Seri, 2004, ss. 20-23).

6 Inne teorie wskazują na Arabię, Indie, a nawet Europę (Portugalię), jako możliwe źródła pochodzenia pierwowzoru kebai.

7 Duże znaczenie dla powszechności szytych elementów odzieży miało pojawienie się na tych terenach, sprowadzonej z Europy, maszyny do szycia, wynalezionej przez Isaaka Singera w 1854 roku (patrz: Taylor, 2010, s. 105). 
tzw. kemben, oraz otwartego żakietu. Kebaya taka noszona była najczęściej w taki sposób, aby nie zasłaniała albo zasłaniała tylko częściowo pas stagen - przeważnie z samodziału, barwiony na jednolity kolor, który miał za zadanie podtrzymywać batik oraz wyrównywać sylwetkę kobiecą do pożądanego ideału. Bogatsze Jawajki chętniej wybierały model bez dodatkowego materiału pomiędzy połami kebai, zapinany na piersiach na haftki lub dekoracyjne guziki, często wykonywany z welwetu lub jedwabiu, ozdabiany biżuterią, w szczególności broszami i nie odsłaniający znajdującej się ewentualnie pod kebayą tkaniny kemben ani spodniego pasa stagen ${ }^{8}$ Dół stroju nadal najczęściej stanowiła owinięta wokół bioder tkanina. Dodatkowo niektórzy mężczyźni zakładali pod nią spodnie. Wśród arystokracji były to tkaniny batikowane, zaś ludność najuboższa nosiła luriki - bawełniane samodziały o prostej ornamentyce. Lurik był także często wybierany jako materiał służący do szycia górnych części stroju Jawajczyków z niższych warstw społecznych. Batiki nie były więc powszechnym elementem stroju najuboższych, lecz zdobiły przedstawicieli rodów panujących i arystokracji jawajskiej. Ich powszechna dostępność poza murami pałaców wiąże się dopiero z rewolucją w procesie produkcji, zapoczątkowaną W pierwszej połowie XIX wieku. Wprowadzenie stempla (cap), umożliwiającego szybkie pokrywanie woskiem dużych przestrzeni materiału', a następnie sprowadzenie na Jawę sztucznych barwników skróciło czas produkcji i tym samym obniżyło cenę, wpływając na przeobrażenie powszechnie noszonych strojów. Innowacje te zapewniły także rozwój batikarstwa jawajskiego, zagrożonego wcześniej przez zalew taniej i niskiej jakości produkcji europejskiej ${ }^{10}$.

Pod koniec XIX i na początku XX wieku oficjalnym strojem arystokracji jawajskiej był więc drapowany wokół pasa batik, ale w połączeniu z elementami zapożyczonymi z innych kultur. Kobiety nosiły kebaye, mężczyźni zaś odsłaniające pas marynarki, zwane sikepan, z ozdobnymi broszami i zegarkami na dewizkach, oraz koszule z zawiązywanymi pod szyją muchami (patrz: Taylor, 2010, s. 103). Strój męski wieńczyło tradycyjne nakrycie głowy, nazwane blangkon, wykonane z batikowanej tkaniny, ręcznie zawijanej lub - w późniejszym okresie - zszywanej na kształt półkolistego turbanu bądź zawoju. Kobiety z arystokracji nie zasłaniały głowy ${ }^{11}$, zaś włosy spinały $w$ dekoracyjny kok, sanggul. Jedynie w dniu ślubu władca wraz z małżonką występowali w strojach z odsłoniętymi ramionami, w przypadku kobiety, oraz z odsłoniętym torsem, w przypadku mężczyzny. Obydwoje nosili wówczas cenne batiki, dodot, znacznie dłuższe niż mniej galowe kain.

W obrębie dworów jawajskich stroje obowiązujące dworzan i sługi, abdi dalem, pozostawały bardziej statyczne w swej formie od mody poza pałacowymi murami. Jeszcze w połowie XX wieku na dworze sułtana Yogyakarty część mężczyzn abdi dalem nie zasłaniała torsu i nosiła jedynie batikowany kain oraz podtrzymujący go pas ${ }^{12}$. Strój kobiecy

\section{- • • •}

Obecnie model taki najczęściej określany jako tzw. model Kartini, na cześć Raden Ajeng Kartini (1879-1904), działaczki na rzecz kształcenia kobiet, pochodzacej z jawajskiej rodziny arystokratycznej. O życiu i pogladach Kartini m.in. Joost Coté (Coté, 2008, ss. 1-49). W 1964 roku Sukarno ustanowił 21 kwietnia Dniem Kartini.

9 Nowa technika, kusząca niskim nakładem kosztów, spowodowała lawinowe uruchamianie manufaktur (w dużej mierze chińskich) na Jawie, zapewniających liczne miejsca pracy i rozwój nowych ośrodków.

10 Pierwsza manufaktura batiku założona została w Holandii w 1835 roku.

11 Kudung upowszechnił się w drugiej dekadzie XX wieku, wraz z działalnością islamskich organizacji takich, jak 'Aisyiah (patrz: Kurniawati, 2012, s. 121).

12 Taylor pisał (Taylor, 2010, ss. 102-103), że już w drugiej połowie XIX wieku mężczyźni na dworach nie odsłaniali torsów, jednak w analizowanych przeze mnie kolekcjach prywatnych znajdują się zdjęcia przeczące jego twierdzeniu. Niemniej prawdą jest, że coraz powszechniejsze było wówczas zakrywanie górnej części ciała, obecnie uważane za wymóg formalny. Zob. m.in. kolekcja fotografii rodzinnych sułtana Yoyakarty Hamengkubuwono IX (1940-1988), własność BRAy Hj.Poeroeboyo, Yogyakarta (zbiór nieuporządkowany). 
abdi dalem ulegał jeszcze mniejszym przekształceniom i do dzisiaj obowiązujący pozostaje batikowy kain ${ }^{13}$ oraz podtrzymujący go stagen ukryty pod tkaniną kemben ${ }^{14}$.

Na początku XX wieku mężczyźni z arystokratycznych rodzin jawajskich coraz chętniej wybierali pełny strój europejski, zarówno na uroczystości prywatne, jak i oficjalne. Jedynie jawajskie ceremonie pałacowe wymagały tradycyjnych jawajskich strojów batikowych. Co charakterystyczne, nie rezygnowano z utrwalonych w tradycji wzorów o hinduistyczno -buddyjskim rodowodzie, którymi zdobiono tkaniny nawet, jeśli noszący ją arystokrata wyznawat islam.

Tkaniny batikowe budziły coraz większe zainteresowanie Europejczyków, którzy w końcu XIX i na początku XX wieku chętnie nosili je w zaciszu domowym (Locher-Scholten, 2004, s. 204). Europejskim pomysłem było wykorzystanie ich także do dekoracji domów oraz cięcie i zszywanie z nich nowych elementów strojów, poza tradycyjnymi kuponami kain, ewentualnie mniejszymi i chętniej wybieranymi przez Europejczyków sarongami. Powstawały więc batikowe obrusy, spodnie bądź piżamy. Wykorzystanie sztucznych barwników umożliwiło tworzenie batików o znacznie szerszej gamie kolorów niż tradycyjne na Jawie Centralnej biel, krem, odcienie brązu, niebieskiego i żótć, podsycając jeszcze to zainteresowanie. Europejki nosity w domach batikowe spody, zestawiane z białymi haftowanymi kebajami.

Jawajczycy z niższych warstw społecznych nie mogli nosić strojów europejskich ${ }^{15}$. Za tych, którym przysługiwały prawa "równe Europejczykom”, uznano m.in. członków rodów panujących. Także ludność miejscowa wyznająca wiarę chrześcijańską miała ubierać się zgodnie z modą europejską (za: Heringa \& Veldhuisen, 1996, ss. 49-50; patrz: Adam, 2014, ss. 16-19). Pozostali mogli nosić tylko przysługujące im stroje lokalne. Jeśli pracowali w administracji państwowej, zakładali kain i sikepan, a na głowę blangkon. Nogi pozostawały bose. Determinowało to całe spektrum zachowań. Ubrani w ten sposób Jawajczycy musieli przyklękać, wchodząc do pomieszczenia, w którym znajdowali się Holendrzy, nie wolno było im siadać na krześle, lecz na podłodze, zaś podchodząc do Holendra w urzędzie, byli zobowiązani do zachowania specyficznego kroku, wymagającego utrzymania się w stałej pozycji półuklęku (Adam, 2014, s. 13). Rodzące się dziennikarstwo indonezyjskie określało te stroje i zwyczaje mianem adat Madjapaitan (Adam, 2014, s. 13), czyli tradycje/prawo tradycyjne Majapahit, odnosząc się do hinduistyczno-buddyjskiego królestwa, panującego w regionie do piętnastego wieku. Wykształciła się wówczas hierarchia, w której pozycję manifestował między innymi strój. Określenie adat Madjapaitan stato się synonimem poddania się i biernego przyjmowania kolonialnej w kategoriach relacji kawula-gusti, czyli zwierzchności sługa-pan ${ }^{16}$.

Stopniowe zmiany, powoli przeobrażające stosunki Europejczyków i rdzennych mieszkańców Indii Holenderskich, a możliwe w dużej mierze dzięki wprowadzeniu „Polityki Etycznej"17, wpłynęły również na przełamanie zakazu dotyczącego noszenia strojów europejskich. Na początku drugiej dekady XX wieku niektórzy studenci, zwłaszcza uczęszczający do Szkoły Kształcącej Rodzimych/Rdzennych Lekarzy (School tot Opleiding van

13 Przy czym nadal obowiązuje ścisła hierarchia motywów, które mogą zdobić tkaniny noszone przez abdi dalem, wyższych rangą dworzan spokrewnionych z dworem, a wreszcie najbliższą rodzinę sultana.

14 Kobiety abdi dalem noszą także wąski pasek materiału w jednolitym kolorze zależnym od rangi, podtrzymujący krótki tradycyjny sztylet kobiecy, wedung.

15 Nie wolno im było także rozmawiać w języku holenderskim.

16 Więcej na temat relacji kawula-gusti (patrz: Moertono, 1981, ss. 14-20).

17 Młoda królowa Wilhelmina wprowadziła Politykę Etyczną w przekonaniu o moralnym obowiązku, jakim miało być dla przedstawicieli cywilizacji europejskiej przewodnictwo w edukacji, industrializacji i rozwoju Indii Holenderskich. Polityka ta wiązała się także ze zmianami w podejściu do rdzennych mieszkańców Kolonii (za: Wacławek, 2015; Bloembergen, 2006, s. 225; Adam, 1996, ss. 21-26). 
Inlandsche Artsen, STOVIA), odważyli się założyć europejskie ubrania, albo przynajmniej niektóre elementy stroju europejskiego, które łączyli z jawajskimi batikami i tradycyjnymi nakryciami głów (Adam, 1996, s. 23). W ich ślady poszli urzędnicy niższych stopni, nauczyciele, sekretarze, sklepikarze, działacze nacjonalistyczni i dziennikarze (Adam, 1996, s. 23) ${ }^{18}$. Rodzący się nacjonalizm nosił więc nie rdzenny, lecz europejski strój. Był także rodzaju męskiego, gdyż kobiety nadal w większości zakładały stroje tradycyjne, niekiedy tylko przełamywane europejskimi dodatkami, na przykład podczas podróży do Europy ${ }^{19}$. Mężczyźni zazwyczaj z chęcią zamieniali batikowy kain na dające więcej swobody europejskie spodnie i koszule, umożliwiające także przemianę sposobu zachowania w obecności Europejczyków; ten, kto nosił strój europejski, nie był zobowiązany do określonych zachowań, na przykład nie musiał siadać na podłodze, lecz na krześle. „Nosząc stroje europejskie, mieszkańcy kolonii przełamywali zarówno hierarchię tożsamości utrwaloną przez tradycję, jak i hierarchię tożsamości kolonialnej" (Adam, 1996, ss. 26-27). Wkrótce ci, którzy trwali przy noszeniu tradycyjnych strojów, zaczęli być odbierani przez dziennikarzy jako wrogowie (Adam, 1996, ss. 28-29). Adam cytuje fragment jednego z artykułów siódmego numeru gazety „Doenia Bergerak” z 1914 roku:

Hej, Jawajczyku, jaki jest cel w tym, żebyś odrzucit twój kaen [kain, batikowany materiał]? Żebyś zamienił go na buty i garnitur? Ponieważ, jeśli nosisz ten strój, nie będziesz kłaniał się ani zginał swoich kolan przede mną (...) hej Jawajczyku, nie odrzucaj tego zwyczaju, ponieważ twoje zwyczaje pokazują, że jesteś posłuszny, a teraz oddaj mi swoją ziemię! (za: Adam, 1996, ss. 29-30).

Odrzucając tradycyjny strój mieszkańcy Indii Holenderskich odrzucali oczywistość koIonialnej dominacji. Kiedy prezydentem niepodległej Indonezji został Sukarno, pojawiła się silna presja, aby ostatecznie zwalczyć ten „feudalny symbol”, promując na jego miejsce symbol nowego kraju, jednoczący wieloetniczny, wielorasowy i wieloreligijny tygiel. Jednak nawet wśród równych, ktoś pozostaje „równiejszym”. Spośród co najmniej 250 grup etnicznych, Jawajczycy stanowią około 47\% całej populacji (por. Suryadinata, 2000, s. 39) i to z Jawy pochodzili wszyscy prezydenci Indonezji20. Wcześniej, w czasach kolonialnych, to przekształcony strój jawajski przez kilka dziesięcioleci był chętnie wybierany na prywatne okoliczności przez Europejczyków mieszkających w Indiach Holenderskich. Chociaż Sukarno zdecydowanie zwalczał noszenie tradycyjnego stroju przez mężczyzn, był zdania, że najodpowiedniejszym strojem dla kobiety, manifestującym jej narodowość, będzie zestaw: kebaya i batikowy kain. Włosy, spinane w kok lub splatane w warkocze w przypadku młodszych dziewcząt, pozostały odkryte, ewentualnie lekko zakrywał je kudung. Batik w stroju kobiecym miał wyrażać dumę z bycia Indonezyjką, mieszkanką kraju kontynuującego szlachetne tradycje królestw Sriwijaya i Majapahit ${ }^{21}$. Obydwa jawajskie królestwa

\section{- •. •}

18 Adam wspomina o okólniku nr 2014, skierowanym przez Gubernatora Indii Holenderskich do zwierzchników lokalnych urzędów administracyjnych w 1913 roku, a opublikowanym przez dziennikarzy gazety "Doenia Bergerak" w numerze 32. Chociaż sam okólnik nie dotyczył stroju, lecz przypominał o nakazie zmiany sposobu powitania zwierzchników holenderskich przez jawajskich urzedników niskiej rangi, na "normalny” i „właściwy”, czyli europejski, „dziennikarze wykorzystali go, aby przekonać masy do zmiany stroju na styl europejski" (za: Adam, 1996, ss. 25-26).

19 Stan ten powoli ulegał zmianie i w latach trzydziestych oraz czterdziestych kobiety w strojach europejskich, zwłaszcza w Batawii (dzisiejsza Dżakarta), będącą centrum politycznym i kulturowym, stanowiły już powszechny widok.

20 W kolejności: Sukarno, Suharto, Bacharuddin Jusuf Habibie (urodził się na Sulawesi, był w połowie Bugisem, w połowie Jawajczykiem), Abdurrahman Wahid, Megawati Sukarnoputri, Susilo Bambang Yudhoyono, Joko Widodo (obecnie).

21 W przemówieniu z 1 czerwca 1945 roku, nazwanym później „Narodzinami Pancasili” (Lahirnya Pancasila), Sukarno budował obraz wielowiekowej tradycji obecnej Indonezji, uzasadniając (nieco na wyrost), wynikającą z historii oczywistość stworzenia niepodległego kraju właśnie w tych granicach. Mówił m.in.: „Jedynie 
dominowały nad ogromnymi obszarami, umożliwiając mieszkańcom odległych terenów podlegających ich wpływom, na kontakt z wyrafinowaną kulturą jawajską. Kobieta Indonezyjka ubrana w batik i kebaję, uwidaczniała więc wykorzystanie tego samego wątku, z którego od kilkuset lat tkano historię rejonu. Wątek batikowy miał teraz szansę na nowo złączyć rozrzucone [w domyśle: choć stanowiące niegdyś całość] skrawki kultur, w kulturę wspólną, indonezyjską. Ciało kobiety miało być przestrzenią demonstracyjnej kontynuacji, przywiązania do tradycji. W tym samym czasie ciało mężczyzny symbolizowało wejście Indonezji na drogę współczesności. Sukarno promował dla mężczyzn strój zachodni, argumentując, że noszący go człowiek nie ma służalczej postawy, przestaje być bezimiennym sługą, lecz porusza się wyprostowany, „jak każdy biały mężczyzna” (za: Taylor, 2010, ss. 107-108). Powszechne stały się więc wojskowe koszule lub marynarki oraz spodnie z mankietami; popularnym wyrazem indonezyjskości stało się noszenie przez mężczyzn peci. Strój ten był symbolem równego statusu wszystkich Indonezyjczyków. W każdym razie wszystkich mężczyzn.

Chociaż na zachowanych zdjęciach żony Sukarno niezmiennie ukazywane są jako matki narodu²2, w kebai oraz batiku, Indonezyjki, zwłaszcza te jeszcze niezamężne, równie chętnie jak mężczyźni przyjmowały strój europejski. Kiedy wychodziły za mąż, Jawajki często zakładały kain i kebaję, lecz panny wybierały swobodę ruchów w spodniach, koszulach z krótkimi rękawami oraz sukienkach i spódnicach. Strój pierwszej damy nie był uznany za jedyny dopuszczalny, nawet podczas uroczystości państwowych, gdyż wiele kobiet, także na Jawie, wolało ubierać się zgodnie z modą europejską. Podczas uroczystości lokalnych wciąż zakładano stroje tradycyjne dla danej społeczności bądź decydowano się na strój europejski, jako bardziej uniwersalny. Mieszkańcy pozostałych wysp, zwłaszcza tych najbardziej oddalonych od politycznego centrum, chętniej akceptowali strój europejski niż, odbierane jako jawajskie, zestawienie kebai i batiku. Dzieci - najmłodsze pokolenia wolnych Indonezyjczyków - niezależnie od płci nosiły do szkół stroje europejskie: koszule z krótkimi rękawami i spódnice lub spodnie.

Próbą odejścia od prymatu wzornictwa charakterystycznego dla Jawy, a odziedziczonego po wiekach panowania królestw hinduistyczno-buddyjskich, było stworzenie nowych motywów batikowych, mających wyrażać jedność narodu Indonezyjskiego, ponad podziałami etnicznymi i kulturowymi. O stworzenie "batiku nasional" Sukarno poprosił Jawajczyka chińskiego pochodzenia, Go Tik Swana, uhonorowanego później przez dwór w Surakarcie jawajskim tytułem Kanjeng Raden Temengung Hardjonagoro (Trisna, 2014). Wywodzący się z rodu batikarzy Go Tik Swan interesował się filozofią i sztuką jawajską. Swoje unikatowe kompozycje wykorzystujące stare i nowe motywy barwił, mieszając barwniki naturalne i sztuczne. Stworzył batik już nie tyle jawajski, ile indonezyjski, poparty przez Sukarno, który zapoczątkował modę na batik nasional, propagowany także poza Jawą.

Pomimo nowej jakości batiku „ponad podziałami”, Indonezja wkroczyła w drugą połowę XX wieku ubrana głównie w stroje europejskie bądź, jak miało to miejsce zwłaszcza w wiejskich rejonach, tradycyjne stroje regionalne. Analizowany materiał fotograficzny pozwala wysunąć wniosek, że także Jawajki, o ile nosiły batiki, nadal wybierały wzory

dwa razy w przeszłości doświadczyliśmy bycia narodem, za czasów [królestwa] Sriwijaya i za czasów [królestwa] Majapahit" (tłum. Joanna Wacławek). Cały tekst przemówienia dostępny w języku indonezyjskim w: Soekarno, 2013.

22 Zarówno Fatmawati, jak też czwarta z kolei, Hartini, którą Sukarno poślubił w 1952 roku, po separacji z Fatmawati (separacja bez rozwodu), a także piąta żona, Kartini Manoppo, poślubiona w 1956 roku, i siódma, Haryati, poślubiona w 1963 roku. 
zakorzenione w tradycji. Młodzi Indonezyjczycy obydwu płci najczęściej nosili koszule z krótkimi rękawami, spodnie, zaś dziewczęta także często krótkie sukienki bez rękawów, krótsze lub dłuższe spódnice i obcisłe bluzki.

Upadek rządu Sukarno i przejęcie władzy przez generała Suharto, będące początkiem dyktatury trwającej od 1967 do 1998 roku, zapoczątkowały przemiany polityczne, których refleksy odbiły się również $w$ formie stroju obowiązującego podczas oficjalnych uroczystości państwowych. Zmianie uległa też pozycja batiku. Analizując dostępne fotografie z lat poprzedzających objęcie władzy przez Suharto, jak i styl lansowany podczas jego rządów, wydaje się, że źródeł oficjalnego stroju kobiecego epoki Orde Baru²3 należy szukać w sposobie ubierania się kobiety związanej jeszcze z poprzednim ustrojem. Wyjątkiem od wizerunku poczciwej, trochę staroświeckiej Indonezyjki, matki narodu, noszącej zazwyczaj prowincjonalny model kebai, batik i kudung, była szósta żona Sukarno, Naoko Nemoto, z którą Sukarno wziął ślub w 1962 roku. Naoko urodziła się w Japonii, była pewną siebie i elegancką kobietą, która nosiła gustowne kebaje, często haftowane, zapinane na piersiach, niekiedy zaś zakładała europejskie stroje, szpilki i ciemne okulary, włosy upinała w wysoki kok i mocno malowała usta. Do tego wizerunku w dużym stopniu odwołała się pierwsza dama Orde Baru, Siti Hartinah, zwana Ibu Tien.

Zamożne Indonezyjki dostrzegły w batikowych kainach i sarongach przedmioty luksusowe, nie tylko podkreślające urodę noszącej je kobiety, ale także pozwalające poczuć się jak arystokratka. Drapowały więc batik ciasno wokół nóg, lekko pod kątem, odsłaniając kostki i wysmuklając ciało w stylu, który do dziś na dworze sułtana Yogyakarty przysługuje jedynie młodym kobietom spokrewnionym z władcą. Zakładały szpilki i coraz bardziej koronkowe, strojne kebaje. Modnym dodatkiem stały się torebki i czarne okulary, a także szal - slendang, przerzucony przez ramię. Batik środkowojawajski wybierany był równie chętnie jak kolorowe batiki ozdobione motywami niełączącymi się z tradycją pałaców suttańskich. Formy wcześniej znanych elementów jawajskiego, uległy modyfikacjom.

„Wzrost populacji w latach pięćdziesiątych i sześćdziesiątych sprawit, że większość Indonezyjczyków żyjących w czasach rządów Nowego Porządku nie miała osobistych doświadczeń z okresu kolonialnego" (Taylor, 2010, s. 109). Rodziła się nowa Indonezja. Nowy był także batik, w który się ubierała. Lata Orde Baru to czas intensywnego rozwoju rynku mody i słynnych projektantów indonezyjskich, m.in. Iwana Tirty, który wypromował ekskluzywny, ręcznie rysowany batik na jedwabiu, swoimi śmiałymi kompozycjami trafiając w gust nie tylko Indonezyjczyków, ale także elity międzynarodowej (Boehlke, 2008, ss. 79-86).

W powszechnym użyciu był jednak nie batik ręczny, lecz stemplowany bądź drukowany na bawełnie, odpowiedni dla powstającej w tamtym okresie klasy mieszczańskiej. W urzędach, szkołach i w rządzie pojawiły się uniformy z elementami batikowymi o ujednoliconych barwach i motywach, charakterystycznych dla konkretnej grupy osób. Uniformizacja społeczeństwa była, jak to ujęła Linda Arthur, metaforą indonezyjskiej świeckiej religii, czyli Pancasila (Arthur, 2000, s. 202), zaś batik stał się elementem wykorzystywanym w jej rytuałach. Wyznaczano dni, w które obowiązkowe było noszenie strojów uszytych z batikowanych materiałów, zwłaszcza koszul, zakładano je także podczas Święta Niepodległości (17 kwietnia). Bawełniana koszula batikowa z długim rękawem, której pomysłodawcą był Ali Sadikin, zainspirowany narodową koszulą Filipińczyków (Boehlke, 2008, ss. 51-52), do dziś jest uważana za oficjalny narodowy strój indonezyjskich mężczyzn. Niekiedy zastępuje ją noszony w zestawie z peci garnitur, niemniej traktowana jest

23 Dosłownie: Nowy Porządek. 
na równi z nim, jako strój galowy. Zwyczaj ten przeniknął do wszystkich warstw społecznych. Koszule takie noszone są do dziś zarówno na dworach sułtańskich, jak i przez ludzi najuboższych.

Przedstawiciele elit i bogatej klasy mieszczańskiej chętnie prezentowali się w strojach narodowych, zwłaszcza podczas oficjalnych spotkań, natomiast najubożsi nosili stroje zachodnie, ewentualnie łączone z batikowanymi koszulami, do pracy zaś zakładali T-shirty, szorty lub dresy. Starsi i w średnim wieku mieszkańcy wsi jawajskich pozostali w większości wierni modzie wykształconej podczas prezydentury Sukarno. Po raz pierwszy tak silnie akcentowano w modzie styl narodowy, traktowany jako nadrzędny w stosunku do etnicznego (Jones, 2003, s. 192). W przypadku niektórych rejonów kraju rząd w Dżakarcie decydował, jak właściwie ma wyglądać dany strój etniczny. Posunięcia polityczne, w rodzaju przeprowadzonej w 1971 roku wśród grup etnicznych Ekari i Dani (Papua Zachodnia), tak zwanej Operacji Koteka, a także systemu szkolnictwa wymagającego noszenie przez uczniów określonych mundurków, zaowocowało stopniowym zastępowaniem strojów, a niekiedy także zwyczajów, lokalnych, przez narodowe (patrz: Howard, 1999, ss. 22-23). Niewygodną tradycję zastępowano jej zmodyfikowaną formą, zgodną z prowadzoną polityką ${ }^{24}$.

Końcowy okres panowania Suharto był czasem narastania tendencji panislamskich w społeczności muzułmańskiej na całym świecie. To zjawisko odbiło się na modzie indonezyjskiej, dając początek obserwowanej obecnie silnej polaryzacji stroju narodowego; w szczególności chodzi o nakrycie głowy Indonezyjek wyznających islam. Od 1982 do 1991 roku Ministerstwo Religii zakazywało noszenia jilbabu ${ }^{25}$ w szkołach, jednak szybko stało się oczywistym, że tożsamość narodowa, manifestowana przez strój, ustępować zaczyna manifestowaniu - także przez strój - tożsamości religijnej. Sam Suharto odbył w 1991 roku pielgrzymkę do Mekki i - jak to ujął Taylor - „'ubrał' swoje imię, dodając do niego tytuł haji (oznaczający pielgrzyma) oraz Muhammad, podczas gdy jego córka Tutut, mająca własne aspiracje polityczne, zaczęła publicznie nosić kudung" (Taylor, 2010, s. 112).

Moda islamska stała się poważnym rynkiem produkcji. W jej obrębie do dziś utrwality się dwie tendencje. Elementy tradycyjnego stroju narodowego, jak batik, adaptowane są, głównie na Jawie, przez muzułmanki chcące podkreślać zarówno swoją tożsamość indonezyjską jak i islamską. Drugą opcją jest odrzucenie elementów kojarzonych z tradycją lokalną (bądź przekształconych w tradycję indonezyjską) i akcentowanie, poprzez strój, przede wszystkim swojej przynależność do ummy².

Rząd Suharto upadt w 1998 roku, a fotel prezydenta Indonezji, po krótkich kadencjach Habibie i Wahida, objęła Megawati Sukarnoputri, córka Sukarno i Fatmawati. Kontynuowała tradycję stroju narodowego, utrwalonego podczas ostatnich dekad, choć na co dzień zakładała strój zachodni. Co jednak najbardziej charakterystyczne, nie zakrywała włosów. Fala krytyki, która przetoczyła się przez media, zarówno podczas jej kampanii jak i prezydentury, ukazała wielkie zmiany, jakie nastąpiły w myśleniu o „odpowiednim stroju”, przede wszystkim w kontekście obowiązków religijnych (patrz: Taylor, 2010, ss. 113-114). Kolejny rząd, generała Susilo Bambanga Yudhoyono, w znacznej mierze stanowił powrót do pełnych przepychu kostiumów z zaplecza dworskiego teatru, jakim był reżim Orde

24 Takie quasi-tradycyjne stroje do dziś prezentowane są w albumach przedstawiających „typy” mieszkańców Indonezji. Obraz ten był przez tak długi czas narzucany przedstawicielom wybranych grup etnicznych, że obecnie niektórzy z nich uważają, iż tak właśnie wyglądają tradycyjne stroje ich własnej społeczności.

25 Z arabskiego hijab, chusta noszona przez muzułmanki, zakrywająca szczelnie włosy oraz szyję. Postanowienie znoszące zakaz (SK No.100/C/Kep/D/1991) wydano w lutym 1991 roku (patrz: Smith-Hefner, 2007, s. 397).

26 Wspólnota muzułmańska. 
Baru, jednak chętnie unowocześnianym strojami z międzynarodowego kręgu kultury popularnej - podczas kampanii Yudoyono pokazywał się w zwykłych ubraniach i dodatkach zachodnich, takich jak sportowa koszula i czapka bejsbolowa (Taylor, 2010, s. 115). Interesującym zestawem strojów posługiwał się podczas kampanii prezydenckiej 2014 roku obecny prezydent, Joko Widodo, zwany Jokowi, decydując się na manifestację niemal wszystkich tożsamości, które mógł ukazać poprzez ubiór. Brał udział w kampanii ubrany w arystokratyczny kostium jawajski, a więc batikowy kain, czarny sikepan oraz blangkon (podobnie jak w poprzednich wyborach przeciwnik Yudhoyono, generał Wiranto (Taylor, 2010, s. 115)), nosił koszule batikowe z długim rękawem albo białe, zaś charakterystyczna kraciasta koszula z podwijanymi rękawami, typowa dla mody amerykańskiej, nazwana została „kemeja Jokowi”, czyli "koszula Jokowi”. Odkrywał głowę, albo zakładał peci, pozował w mundurze, nosił T-shirt, zakładał garnitur, udzielał wywiadu w baju muslim - stroju muzułmanów udających się do meczetu, a wreszcie wystąpił w stroju pielgrzyma, na zdjęciach z pielgrzymki do Mekki, dokąd udał się z rodziną. Powyższe wyliczenie dość wyraźnie pokazuje, że tożsamość narodowa, manifestowana jednym zestawem strojów już nie wystarcza, o ile kiedykolwiek wystarczała ${ }^{27}$. Kostiumów przybywa i być może niedługo indonezyjski strój narodowy ulegnie kolejnym przekształceniom. Wyzwaniem staje się przede wszystkim moda w stylu arabskim, lansowana przez liderów religijnych, także pochodzenia arabskiego, oraz część wiernych. Trudne wydaje się także dalsze żonglowanie licznymi tożsamościami. O ile podczas trwania Orde Baru wizja mozaikowości kultur tworzących Indonezję była pielęgnowana i przedstawiana narodowi, a także obcokrajowcom, niczym fasada zasłaniająca mniej baśniową rzeczywistość, o tyle obecnie Indonezyjczycy stają przed coraz pilniejszą koniecznością zdefiniowania na nowo tożsamości narodowej.

Wśród kolejnego pokolenia Indonezyjczyków nie istnieje silna potrzeba manifestowania w życiu codziennym indonezyjskości poprzez strój. W szkołach, uczelniach i miejscach pracy ubiór symbolizuje teraz przede wszystkim poglądy religijne. Zarazem poza centrum, jakim jest Jawa, nasilają się tendencje separatystyczne, coraz donośniej oznajmiane jest hasto "kami bukan merah-putih"28.

Nie znaczy to jednak, że dekady mniej lub bardziej wprawnego budowania wspólnej tożsamości narodowej nie przyniosły żadnego rezultatu. Batik w pewien sposób połączył Indonezyjczyków, ewoluując jako swego rodzaju symbol indonezyjskości. Tym cenniejszy i żarliwiej broniony, im jego stanowisko wydawało się bardziej zagrożone. Szczególną czujność wzbudziła w Indonezyjczykach pogłoska, że Malezja stara się o wpisanie na międzynarodową listę dziedzictwa kulturowego UNESCO batiku malezyjskiego ${ }^{29}$. Do dziś niektórzy mieszkańcy Indonezji wciąż są przekonani, iż Malezyjczycy czekają na sposobność, aby „ukraść” dorobek kulturowy Indonezji. Batalię o opinię UNESCO Marshall Clarc i Juliet Pietsch odczytali jako wyraźną kontynuację tradycji kolonialnej, kiedy koloni-

27 Niefrasobliwość w obchodzeniu się wizerunkiem, a do pewnego stopnia także chęć sprostania oczekiwaniom jak najliczniejszej grupy wyborców, stała się w drugiej połowie 2014 roku przyczyną kłopotów żony Jokowiego, Iriany Joko Widodo. Podczas końcowych miesięcy kampanii męża, zdecydowała się na założenie jilbabu, którego wcześniej nie nosiła. Szereg zdjęć ukazuje ją zarówno z udrapowaną luźno modyfikacją chusty kudung, jak i w szczelnie zakrywającym włosy oraz szyję jilbabie. Jednak po zakończeniu kampanii znów pokazała się z odkrytą głową, wzbudzając niechętne, bądź wręcz nienawistne, komentarze w prasie oraz na portalach społecznościowych. Krytyczne opinie w rodzaju „pokazała swoją prawdziwą naturę”, albo „jilbab polityczny", należą do łagodniejszych. Nieliczne były głosy broniące swobody kreowania wizerunku, a także zmagania się z własną tożsamością, zgodnie z sumieniem i uczuciami samej Iriany (patrz: Mulyana, 2014; Iriana istri Jokowi, 2014; Hindarto, 2014; O Iriana o Marshanda, 2014).

28 "Kami bukan merah-putih", czyli dostownie „nie jesteśmy czerwono-biali”, co odnosi się do barw flagi indonezyjskiej.

29 Nie znaleziono dowodów na jej poparcie. Malezja nigdy formalnie nie wystąpiła o taki wpis na listę UNESCO (Clark \& Pietsch, 2014, s. 79). 
zatorzy decydowali o uznaniu lub dezaprobacie dla każdego przejawu kultury podległych im ziem, wydając opinię, co można określić jako sztukę/kulturę wysoką, a co jako niską (Clarc \& Pietsch, 2014, ss. 39, 43). Ostateczne wpisanie w 2009 roku na listę UNESCO batiku indonezyjskiego, odebrane zostało powszechnie w Indonezji, jako zwycięstwo nad Malezją (Clarc \& Pietsch, 2014, s. 69). Ustanowiono też narodowy Dzień Batiku, obchodzony w każdą rocznice wydania przez UNESCO tej decyzji, czyli 2 października. Batalia o batik, choć Indonezyjczycy najwyraźniej nie zdawali sobie sprawy, że prowadzona jednostronnie, zmobilizowała naród i stworzyła możliwość zjednoczenia się w obliczu wspólnego wroga. Zaowocowała także masowym zainteresowaniem batikiem. Trwające od co najmniej dwóch dekad w lekkim letargu warsztaty batikarskie zaczęły intensywną produkcję, z galerii z antykami błyskawicznie zniknęły kurzące się od lat stare stemple do batików i same batiki. Wydawano albumy i opracowania naukowe, a utworzone na

Jawie Stowarzyszenie Miłośników Batików Sekar Jagad stało się niemal elitarnym klubem zrzeszających śmietankę wpływowych kobiet i mężczyzn. Stan ten trwa do dziś, pozwalając na chwilowe zapomnienie o dzielących społeczeństwo różnicach i oferując rządowi szansę na wzmocnienie pozycji batiku jako symbolu indonezyjskości, łączącego ponad podziałami.

\section{BIBLIOGRAFIA}

Arthur, L. B. (2000). School uniforms as a symbolic metaphor for competing ideologies in Indonesia. W L. B. Arthur (Red.), Undressing religion: Commitment and conversion from a cross-cultural perspective (ss. 201-216). Oxford: Berg Publishers.

Bloembergen, M. (2006). Colonial spectacles: The Netherlands and the Dutch East Indies at the Word Exhibitions, 1880-1931. (B. Jackson, Tłum.). Singapore: Singapore University Press.

Boehlke, H. L. (2008). Nation as fashion in New Order Indonesia, 1967-1998 (Niepublikowana rozprawa doktorska). University of Minnesota, Minneapolis.

Clark, M., \&, Pietsch, J. (2014). Indonesia-Malaysia relations: cultural heritage, politics and labour migration. New York NY: Routledge.

Datin, S. E. M. (2004). The Nyonya kebaya: A century of straits Chinese costume. Singapore, Vermont: Periplus Editions.

Hellman, J. (2003). Performing the nation: Cultural politics in New Order Indonesia. Copenhagen: Nordic Institute of Asian Studies.

Heringa, R., \& Veldhuisen, H. (1996). Fabric of enchantment: Batik from the North Coast of Java. Singapore: Weatherhill.

Hindarto, S. Y. (2014, październik 20). Lho istri Jokowi kok enggak pakai jilbab?. Okezone. Pobrano 16 grudnia 2015, z http://news.okezone.com/read/2014/10/20/337/1054451/ Iho-istri-jokowi-kok-enggak-pakai-jilbab

Howard, M. C. (1999). Cloth, dress and ethnic identity in Irian Jaya. Irian: Bulletin Irian Jaya Research \& Development, 22(1), 14-31.

Iriana istri Jokowi. (2014, listopad 20). Iriana istri Jokowi tidak pakai jilbab saat pelantikan presiden. Idjoel. Pobrano 16 grudnia 2015, z http://www.idjoel.com/iriana-istri-jokowitidak-pakai-jilbab-saat-pelantikan-presiden/ 
Jones, C. (2003). Dress for sukses: fashioning femininity and nationality in urban Indonesia. W S. Niessen, A. M. Leshkowich, \& C. Jones (Red.), Re-orienting fashion: the globalization of Asian dress (ss. 185-214). New York NY, Oxford: Berg Publishers.

Kurniawati, D. H. (2012). Javanese women and Islam: Identity formation since the twentieth century. Southeast Asian Studies, 1(1), 109-140.

Lesner-Szwarc, R. (2011). Taman Mini Indonesia Indah jako przykład indonezjanizacji kultury Indonezji. Rocznik Muzeum Wsi Mazowieckiej w Sierpcu, 2, 137-149.

Locher-Scholten, E. (2004). Women and the colonial state: essays on gender and modernity in the Netherlands Indies 1900-1942. Amsterdam: Amsterdam University Press.

Luthfi, A. (2014). Transformation of dress and national subject formation of the Indonesian commoners in the colonial period (Equality Development and Globalization Studies Working Paper, Northwestern University). Pobrano 16 grudnia 2015, z http:// www.edgs.northwestern.edu/wp-content/uploads/2014/08/Luthfi_newpaper.pdf

Moertono, S. (1981). State and statecraft in old Java: a study from the later Mataram Period, $16^{\text {th }}$ to $19^{\text {th }}$ century. Ithaca, New York NY: Cornell University Press.

Mulyana, A. (2014, lipiec 27). Kok lepas jilbab, bu Iriana ikutan Marshanda ya?. Rakyat Merdeka Online. Pobrano 16 grudnia 2015, z http://www.rmol.co/read/2014/07/27/165683/ Kok-Lepas-Jilbab,-Bu-Iriana-Ikutan-Marshanda-Ya-

O Iriana o Marshanda. (2014, lipiec 29). O Iriana o Marshanda: jilbabmu mana?. Berita Protes. Pobrano 29 lipca 2014, z http://beritaprotes.com/o-iriana-o-marshanda-jilbabmu -mana.html

Smith-Hefner, N. J. (2007). Javanese women and the veil in post-Soeharto Indonesia. The Journal of Asian Studies, 66(2), 389-420. http://dx.doi.org/10.1017/S0021911807000575

Soekarno, A. (2013). Pidato Lahirnya Pancasila. Pobrano 16 grudnia 2015, z http:// www.contoh-teks.blogspot.com/2013/11/teks-pidato-lahirnya-pancasila-soekarno. html\#Pendahuluan

Suryadinata, L. (2000). Nation-building and nation-destroying: the challenge of globalisation in Indonesia. W L. Suryadinata (Red.), Nationalism and Globalization: East and West (ss. 38-70). Singapore: Institute of Southeast Asian Studies.

Taylor, J. G. (2010). Identity, nation and Islam: A dialogue about men's and women's dress in Indonesia. W M. Roces \& L. Edwards (Red.), The politics of dress in Asia and the Americas (ss. 101-120). Eastbourne: Sussex Academic Press.

Trisna, F. (2014). Batik Indonesia, karya monumental Hardjonagoro. Pobrano 16 grudnia 2015 z http://senandungkata.blogspot.com/2014/04/batik-indonesia-karya-monumental.html

Wacławek, J. (2015). Dlaczego Indonezja nie jest krajem wyznaniowym? Narodziny Pancasili. W S. Gil \& A. Mianecki (Red.), Wspótczesna religijność w Azji PotudniowoWschodniej (ss. 5-25). Toruń: Uniwersytet Mikołaja Kopernika.

Woodward, M. (2011). Java, Indonesia and Islam. Dordrecht: Springer. 